Article

\title{
Visually-Impaired Brazilian Students Learning English with Smartphones: Overcoming Limitations
}

\author{
Miriam Sester Retorta ${ }^{1}$ (iD) and Vera Lúcia Lopes Cristovão ${ }^{2, *}$ \\ 1 Departamento Acadêmico de Línguas Estrangeiras Modernas, Universidade Tecnológica Federal do Paraná, \\ Av. Sete de Setembro 3165, 80230-901 Curitiba, Brazil; msester@utfpr.edu.br \\ 2 Departamento de Letras Estrangeiras Modernas, Universidade Estadual de Londrina, Portal de Versalhes III, \\ 86044-766 Londrina, Brazil \\ * Correspondence: cristova@uel.br; Tel.: +5543-999-780-399
}

Academic Editors: Sonia Rocca and Bryan Smith

Received: 7 February 2017; Accepted: 12 July 2017; Published: 31 July 2017

\begin{abstract}
The aim of this research was to investigate the role of smartphones in teaching the English language to a population of fifteen, visually-impaired Brazilian students. Classroom ethnography was chosen as the methodological design and data generated from classroom observations, didactic materials that were made and posted on apps, and two questionnaires were used. We resorted to descriptive and interpretive analyses as we intended to find linguistic and behavioral patterns regarding the use of information and communications technology (ICT), focusing on smartphones, for communication and learning English. Results show that, at the beginning of the course, students had little to no ability to use smartphones, including apps such as WhatsApp and Facebook mobile. After two years of formal language and smartphone instruction, all students learned how to use their mobile phones, and were able to post and listen to podcasts and written texts on WhatsApp and Facebook mobile in both their native language and in English. The students also engaged in real-life communication events with peers in Brazil and other parts of the world. Mobile-assisted language learning (MALL) helped these students enhance their social and cultural capital.
\end{abstract}

Keywords: multiliteracies; digital literacy; MALL; dysontogenesis; English for the visually impaired

\section{Introduction}

The over 285 million blind or visually-impaired people in the world [1] have had to find ways to learn, play, and work. How do they learn? When one is deprived of one sense, the others are enhanced, such as touch and hearing; thus, the learning process can take place. Materials in Braille, maps and charts in relief, audio equipment, and abacuses are just some examples of instruments that the blind and visually impaired use in order to learn. In addition, what about information and communication technologies (ICTs)? Have ICTs helped the blind and visually impaired to learn and to be included in society? If so, how have the ICTs been used?

The universal right to education was officially established in 1948 by the United Nation General Assembly through the Universal Declaration of Human Rights. Article 26 declares that:

Education shall be directed to the full development of the human personality and to the strengthening of respect for human rights and fundamental freedoms. It shall promote understanding, tolerance and friendship among all nations, racial or religious groups, and shall further the activities of the United Nations for the maintenance of peace. [2] (p. 7)

In the 1990s, the Salamanca Statement [3] and the Guatemala Convention [4] were conceived in order to provide outlines, and to establish criteria to help include the disabled into society. 
The Salamanca Statement established that, in addition to being concerned with the improvement of physical spaces for these people to receive instructions, there is a strong recommendation of the use of technology to help teachers and students to teach and learn.

Appropriate and various kinds of technologies should be used when necessary to promote better rates of success of school curricula and to help these students in communication, mobility and learning. [3] (p. 9)

In Brazil, the Ministry of Education has launched special programs in order to promote inclusion, such as the Inclusive Education Program: the right to diversity [5], the Continuous Formation Program for Teachers of Special Needs [6], the Implementation Program of Multifunctional Resource Classrooms [7], and the Regulation for People with Disabilities [8].

Some publications have also contributed to the development of an inclusive paradigm, such as the Outlines for Special Basic Education [9]; Orientation and Mobility: Basic knowledge for the inclusion of the visually impaired [10]; Pedagogical Working Paper: Building inclusive schools [11], and Knowledge and Practices of Inclusion [12]. However, there are still large legal and scientific gaps, specifically with respect to the blind and visually-impaired community, when it comes to foreign language teaching and learning [13] (p. 15).

This article will report on results of a project in which some visually-impaired students, who were learning the English language, have helped the teaching team to develop ways of using smartphones in order to achieve this objective. The project "English for Us" has been offered to visually-impaired students with the aim of enabling them to learn the English language using ICT; more specifically, smartphones. The idea of using a smartphone to learn a foreign language came from one of the blind students of the group. During a class, while facing difficulty with the Braille materials, one student reported that smartphones were more accessible for blind users than any other ICT. The student stated that "smartphones were even better than computers or laptops because the use of screen readers for PC or laptops were not always efficient with some types of virtual environments like Moodle (Moodle, Inc., Perth, Australia), Edmodo (Edmodo, Inc., San Mateo, CA, USA) or regular Facebook (Facebook, Inc., Menlo Park, CA, USA) whereas TalkBack (Google, Inc., Mountain View, CA, USA) and VoiceOver (Apple, Inc., Cupertino, CA, USA) read almost any page on the phone screen".

Therefore, the objective of this study was to investigate how smartphones could be used as assistive technologies to teach the English language to visually-impaired students. To achieve our goal, we set three specific objectives: search for new apps for smartphones that could be used for English-language learning; investigate how the blind students use smartphones to communicate and learn English; and evaluate the learning process of using smartphone apps in order to learn English.

The current research is based upon data that were previously gathered as part of an extension project developed and conducted at the Federal University of Technology-Paraná (UTFPR). A description of the data is provided in the methodology section. The current research, based on these data, was carried out at the post-doctoral level by the first author Miriam Retorta within the Postgraduate Program in Language Studies at the State University of Londrina (UEL), in collaboration with Vera Cristovão, the second author. This research project was approved by the program and additional approval by the local ethics committee was not mandatory.

This article will be divided into four parts. First, we contextualize this study, explain its purpose and significance, define the theoretical concepts which underlie our study as well as report on some key publications related to the field (Section 1). In Section 2, the research design, methodology, and analysis adopted are outlined, as well as the context of the study. In Section 3, we present and discuss the results. We close this paper with a possible future research perspective.

\section{Review of Literature}

As this study analyzes the role of smartphones in the learning process of the English language by visually-impaired students, we decided to use the digital literacy concepts proposed by Lankshear and 
Knobel as theoretical support [14-16], which converge on the design of multiliteracies, coined by Cope and Kalantzis [17-20], and the new literacies, multiliteracies, and critical literacies in language-teaching development postulated by Monte Mor [21-23], as well as Vygotsky's theoretical concepts of socio interactionism [24,25] and Vygotsky's concept of dysontogenesis [24,26]. We also resorted to the theoretical support of Mobile Literacy by Pegrum [27], United Nations Educational, Scientific and Cultural Organization (UNESCO) [28], Traxler [29], Laurillard [30], and Rheingold [31].

Lankshear and Knobel [14] (p. 2) define literacy as "the relationship between human practice and the production, distribution, trading, refining, negotiating and contesting meaning". In this sense, "identifying literacies as social practices is necessarily to see them as involving socially recognized ways of doing things" [14] (p. 3).

The concept of digital literacies that was adopted for this study is that postulated by Lankshear and Knobel [14] (p. 13), which is the ability to understand and use information in multiple ways, and from a great variety of sources, which are available via computer and, particularly, by the mediation of the Internet. According to these researchers, digital literacies allow us the possibility of combining a way of communicating with the information we intend to teach or give to someone.

Literacies related to technology result in digital literacy (DL), which, according to Lankshear and Knobel [15] (p. 5), is the "many social practices and conceptions of engaging in the construction of meanings mediated by texts produced, received, distributed and exchanged through digital coding". Thus, being digitally literate means, not only knowing how to use information and communication technologies and the apparatuses in favor of knowledge processing, that is say, to read the information and content presented to us, but also to grasp, analyze, and critically judge these pieces of information and content, building and rebuilding new knowledge from them.

Following this line of reasoning, Cope and Kalantzis [17-20], deepened the discussion and developed the concept of multiliteracies, which may be understood as the uniting of significant and increasing growth of cultural diversity and human language in order to increasingly influence new information and communication technologies, i.e., the significance and meanings of things are built and reconstructed in several different ways, multimodal ways, surpassing the writing barrier, and making essential the visual, auditory, tactile, gestural, and spatial construction and reconstruction of these meanings and directions. Thus, "the modes of meaning are intertwined in our representation and communication practices" [18] (p. 191), which differs "according to culture and context, and specific cognitive, cultural and social effects." [18] (p. 5).

From this perspective, Cope and Kalantzis point out that students are seen as builders of singular meanings, able to transform the world in which they live [18]. They are individuals who understand life in its full multiplicity and who are, therefore, active, critical, and engaged; they, not only realize the realities in which they live, but also try to change and improve the world in which they live in, understanding its multiplicities.

In this manner, when students become multiliterate, these individuals start to be effectively recognized as citizens, since they have the power to influence and change their lives, families, schools, communities, and, ultimately, society as a whole, i.e., they become empowered.

Narrowing down the theme to specifically foreign language teaching, Monte Mor points out that "literacy theories defend a perspective of language teaching that takes into account heterogeneity, languages in their diversity, multicultural visions, relevance of the global and local views" [21] (pp. 47-48). In addition, the author points out that it is important that we redefine the objectives of foreign language teaching, so that our teaching focuses on citizenship, plurality, and diversity [23]. Thus, in 2004, Monte Mor proposed foreign language teaching built on the theory of multilearning, i.e., a teaching that may enable students to develop their sense of citizenship, expand their views on culture, broaden their understanding of who they are in relation to others when communicating in a foreign language (identity-otherness relation) and enrich learner perspectives on plurality, diversity, and multiplicity that are present in today's society (various and different forms of communication, cultures and identities, languages, and modalities) [21] (pp. 45-46). 
Monte Mor also advocates that the process of interpreting reality must broaden knowledge and perception about it, keeping in mind that there is no absoluteness regarding it, and that the concept of truth must be understood within a localized context [22] (p. 475). This scholar also states that meanings must be viewed as multiple, questionable, and culturally and socially constructed within power relations. These perspectives would summarize what is meant by critical education, which emphasizes the development of critical awareness and perception.

Within the multiliteracies paradigm, mobile literacy is an emerging and quickly-growing area of study for various reasons. One of them is the continuous and steady growth of citizens who own a mobile phone and, therefore, a great number of people are able to communicate and have (even more) access to information. In 2017, the number of mobile phone users is forecasted to reach 4.77 billion [32] relative to the 7.5 billion inhabitants in the world [33]. In Brazil, 89.5 million people will own a mobile phone in 2017 [34], almost $42 \%$ of the population [35]. Rheingold describes this tendency as the beginning of the next social revolution [31].

Another reason for owning mobile phones is that they can be used anywhere at any time. Pegrum claims that, due to the new scenario of mobile phone accessibility, "not only are these devices mobile; more and more, so are we" [27] (p. 2). Handheld devices allow us to socialize, learn, and work across multiple real-world settings. "New Nomadism" is the term that Pegrum borrowed from The Economist in order to refer to people, from all over the world, who may experience mobility and connectivity, anywhere and at any time [27] (p. 2).

Laurillard endorses this premise, advocating that the "mobility of digital technologies creates intriguing opportunities for new forms of learning because they change the nature of the physical relations between teachers, learners and the objects of learning" [30] (p. 154), including what, as well as where and when, learners are learning. The emphasis that Laurillard outlines, when advocating for mobile technologies, is more on the nature of the physical environment in which the learner is placed, and, hence, the digitally-facilitated site-specific learning experience that is now possible [30] (p. 156).

Still converging on the same issue, UNESCO states that Mobile Technology is ubiquitous [28] (p. 7), and Traxler claims that mobile phones have created "simultaneity of place" [29] (p. 151), i.e., when physical space and virtual space of conversational interaction takes place, as well as when an extension of physical space, through the creation and juxtaposition of a mobile social space.

The fast-growing Mobile Literacy paradigm led UNESCO to define policy guidelines for mobile learning in 2013. This guideline includes some more advantages to mobile learning.

- It expands the reach and equity of education. As previously argued in this paper, mobile phones are digital, easily portable, are usually owned and controlled by an individual rather than an institution, can access the Internet, have multimedia capabilities, and can facilitate a large number of tasks, particularly those related to communication; additionally, since prices have been declining, more people have been able to own a device.

- It facilitates personalized learning. As mobile phones are generally owned by their users, and because they are customizable and carried throughout the day, they lend themselves to personalization.

- They provide immediate feedback and assessment. "Projects have demonstrated that mobile technologies can streamline assessments and provide learners and teachers more immediate indicators of progress" [28] (p. 13).

- They enable, at any time and in any place, learning, as previously discussed in this paper.

- They ensure the productive use of time spent in classrooms. Investigations have revealed that mobile devices can help instructors to use class time more effectively [28] (p. 16).

- They build new communities of learners. Communities are no longer solely based on geographical proximity, and new "tribes" are developing and dissolving according to interests, study and work patterns, and opportunities [31]. 
- They support situated learning. Learning is no longer confined to the four walls of a classroom. Learning can be moved to settings that maximize understanding.

- Mobile devices enhance seamless learning. Due to the fact that information might be stored on remote servers, students can access various types of material from a wide variety of devices (including smartphones, tablets, PCs, and laptops).

- Mobile phones bridge formal and informal learning. Because of their "blurring boundaries between formal and informal education, students can easily access supplementary materials in order to clarify ideas introduced by a classroom instructor" [28] (p. 21).

- These devices minimize educational disruptions in areas suffering conflict and disaster. The infrastructure of mobile technologies is usually easier and quicker to repair following a disaster or conflict than those of other infrastructures [28] (p. 22).

- They improve communication and administration. Since these devices are, in general, less expensive than others, teachers and students are increasingly using them to share information.

- They maximize cost-efficiency; the cost of educational resources may become less expensive.

- Mobile devices assist learners with disabilities. Our visually-impaired students endorse UNESCO's benefits of using these devices to learn. Text-enlargement, voice-transcription, location-awareness, and text-to-speak technologies are some of the settings that largely improve the learning of students with disabilities.

Another aspect that has been noted by some researchers is motivation. Laurillard [30] (p. 156), based on Jones et al. [36], claims that the affective forms of motivation, afforded by mobile learning, are the control that students have over their objectives and goals, the sense of ownership of a device, the fun they have using them, the communication that these students are able to establish with anyone, learning-in-context, which makes learning meaningful, and the continuity between contexts that teachers and students may experience.

Mobile-assisted language learning (MALL), a subset of mobile literacy, has brought new dynamics to the learning of foreign languages. Kukulska-Hulme et al. state that "mobile-assisted language learning is not simply the transfer of current teaching and learning materials and practices to a mobile device, but a complete reconceptualization of these" [37] (p. 3). For these researchers,

Students carry with them devices with which they can create and share multimodal texts, communicate spontaneously with people anywhere in the world, capture language use outside the classroom, analyze their own language production ad learning needs, construct artefacts and share them with others and provide evidence of progress gathered across a range of settings in a variety of media. [37] (p. 7)

Although MALL potentially offers many advantages for language learning, it may also bring all sorts of challenges: affordability, distraction, inequality, lack of skill, and disabilities among others. However, once these difficulties are overcome or minimized, these devices may become a strong ally to improve and promote learning, especially when it comes to the education of visually-impaired students. Mobile devices have come to change interactions and behaviors.

The concepts of DL, multiliteracies, and ML seem to be intrinsically related and permeate all spheres of human activities, including the various areas of teaching and learning. Related to these concepts is the social interactional Vygotskyan theory of mediated learning, where learning is based on the interaction of a child with others and the environment. According to this psychologist, "the process of learning something goes from the child to the object and vice versa through the mediation of another person" [25] (p. 24). Thus, the process of learning and the development of children are "strongly rooted in the connections between their own individual history and their social history" [25] (p. 24). An infant only learns when he/she is in contact with an adult who can mediate between the child and knowledge.

In this sense, social aspects play an essential role in the intellectual and cognitive development of individuals, as it is through the interaction between a child, adult, and the environment that the 
child perceives and understands the realities that surrounds him/her; who formulates concepts and hypotheses, as well as refutes established concepts and hypotheses. In addition, learning also occurs through the interaction between language and action, in which the former is a key part in building and internalizing concepts, as it is through language that mediation takes place between the individual and objects and in the formation of higher intellectual functions. Thus, language is the link between man, the environment, and knowledge.

Based on these concepts, Vygotsky developed the concept of the zone of proximal development (ZPD), which is defined as:

The distance between the actual level of (a child) development determined by his/her ability in solving problems independently and the level of potential development ability of solving a problem under mediation of an adult guidance or in collaboration with more capable companions. [25] (p. 86)

In other words, ZPD is the distance between what the individual can do alone and what he/she is not yet able to accomplish alone, having to rely on the support of other members of their group.

At school, teachers should mediate learning using strategies, techniques, and various resources in order to help his/her students become autonomous, independent, self-sufficient, and encouraging them to achieve potential knowledge and, thus, continuously move on to new ZPDs.

Therefore, "properly organized learning results in mental development and triggers various processes of development that would otherwise be impossible to happen" [25] (p. 24). That is to say that, for development to take place, it is necessary to organize learning so that the teacher mediates the interaction between his/her students and the different content presented to them, allowing his/her students to have access to diverse knowledge. However, this teaching should allow his/her students to build their own knowledge and to develop their own ideas and concepts, as well as to question, refute, and rethink their ways of thinking.

In accordance with this argument, Vygotsky also developed the theory of dysontogenesis, which "implies a positive social vision of children with disabilities, giving preference to the strengthening and training the skills of these individuals, instead of traditionally stressing on their weaknesses, difficulties and deviations" [26] (p. 4).

Although Vygotsky does not view "disorder" as a tragedy, he claims that "psychological-physical insufficiency is determined by a certain social setting, arrangement, or 'aberration', hindering children's normal socialization" [26] (p. 11). These settings may cause a number of disorders in the social behavior of a child, often leading the child to be excluded from the community where he/she lives. This psychologist distinguishes three levels of disabilities: Primary disability (organic impairment), and secondary and tertiary disabilities (cultural distortions of socially conditioned, higher mental functions) [26] (p. 11). According to Vygotsky:

The structure of disability is too complex in order to be studied by simply summing up symptoms. Primary disorders (i.e., visual and hearing, language and speech-related, motor and CNS-related impairment) lead to the child's "exclusion" from the socio-cultural, traditional and educational environment-in turn causing secondary (socio-cultural) disability. Due to primary disorders, the child displays a distorted connection to culture as a source for development of higher mental functions. [26] (p. 11)

These three levels of disability are interrelated and interdependent, and any influence and/or change in one level will affect the others.

It is from the differentiation of these levels that Vygotsky explains that "children with disabilities tend to have a particular need for 'adaptations'" and that "the adapted educational environment can provide the necessary conditions for the 'cultural introduction' of children with disabilities and realization of socio-cultural experience" [26] (p. 11). This means that school, as well as family, friends, church, work, and other social spaces, should provide and subsidize situations, allowing all possible 
social interactions, in order to promote and stimulate learning by any person with a disability, which includes our visually-impaired students. Vygotsky's claim, postulated in the 1930s, converges with the Salamanca Statement for social inclusion.

Other concepts and theories related to teaching English to the visually impaired have been discussed in Brazil and abroad, although this field is still embryonic. In this sense, the following section focuses on reviewing material within the area of Applied Linguistics and Education, mostly in Brazil, and two other research works from other parts of the world.

Dantas offers us a cartography of the Brazilian legislation towards inclusive education, which is mostly done in regular schools nowadays [13] (pp. 33-56). Another important factor are the different actions carried out by the government in order to contribute in-service education towards the teaching of students with special educational needs. Although such legal measures have been taken in Brazil, practically nothing specific for the visually impaired has been mentioned or implemented. Multilitercies and digital and mobile literacies for this group are still not a concern in the legislation.

Fontana reported some figures related to the blind, and some of the difficulties they face in their daily lives and in their educational processes [38] (pp. 54-76). In order to approach the issue, Fontana reported on his experience of working with blind or visually-impaired students in projects related to both undergraduate language teaching courses and the teaching of Spanish using Audacity, a free audio editor and recorder. The material was organized towards themes (such as family, healthy food, entertainment, etc.), a forum (with questions to foster discussion), a text (to be read or listened to), followed by questions to be answered in the target language (if possible). The following sections focus on: (i) the use of every-day situational language, related to the themes covered in the previous text; (ii) knowledge regarding historical and cultural aspects referring to the theme; (iii) the interpretation of questions, such as in a quiz; (iv) the disclosure of curiosities and other types of data; and (v) the evaluation of the work. All the work involves the editing of audio and the engagement of a large number of people. The author stressed the importance of inclusive education and technologies.

Malta presented blind students' learning styles and the possible strategies they develop to learn, so as to make teachers aware and informed as to the kinds of pedagogical resources they need to prepare [38] (pp. 77-100). Regarding learning styles, Malta found cognitive (dependent, global, and impulsive), sensorial (kinesthetic, auditory), and personal (extroverted) to be the most outstanding ones. For strategies, memorization, cognitive, and metacognitive strategies were those with the highest usage. Thus, didactic activities should involve interactions. Malta does not bridge these students' learning styles to possible ICT usage in order to enhance the learning process.

Retorta and Bork report on the experiences of eight pre-service English teachers of the Federal University of Technology-Paraná (Curitiba, Brazil), who aimed at using Information and Communication Technology in order to teach English as an additional language (AL) to visually-impaired students [39] (p. 209). These undergraduate students were taught by three blind students on how to use software programs, which convert text into "synthesized speech" allowing the user to alternatively listen to content, such as DOSVOX [40], NVDA [41], and JAWS [42] on PCs and laptops. They also investigated how some Brazilian blind students commonly used e-mails, cell phones, and social networking sites. Subsequently, they taught the remaining visually impaired, who were digitally illiterate, how to use ICT-mp3 players, laptops, smartphones, PCs-to communicate and learn English. Finally, they found how they could use social networking, such as Facebook, WhatsApp (WhatsApp Inc., Mountain View, CA, USA), and Edmodo, as a virtual environment for teaching/learning and developing didactic materials_-podcasts and written PDF exercises-in order to offer these visually-impaired students technological solutions to communicate and learn English.

Czarneski investigated how a group of visually-impaired students could use Facebook as a virtual environment for learning to help blind students in the process of learning English [43]. Within the Project "Basic English for visually-impaired students" held at the Federal University of Technology-Paraná, Czarneski conducted action-research, grounded in the concepts of Vygotsky's sociointeracionism [25] and Lankhsher and Knobel's Digital Literacy [14-16], throughout 2014. Among 
the results of this work, it was possible to perceive that Facebook can be used as a virtual learning environment (VLE). However, it was noticed that not all students, for many reasons, were able to learn how to access Facebook, and, therefore, other technological resources available were used in order to ensure that all students could have access to the language content.

Oliveira also conducted research with visually-impaired students in the same project "Basic English for visually-impaired students" at the Federal University of Technology-Paraná [44]. This young researcher studied how blind and visually-impaired learners use ICT to communicate and learn English as an additional language. Based on Cope and Kalantzis [17-20], Lankshear and Knobel [14-16], and Glister [45], she collected data using questionnaires, interviews, as well as class observations. Oliveira came to the conclusion that different learners use ICT in different ways in order to learn an additional language. However, when ICT is available to them as a group, they will help each other to find the best ways for each one to adapt to each ICT, and to learn how to use them, as well as to learn the English language. When the visually-impaired group could not find solutions to their problems, they would resort to available sighted pre-service teachers, who would, together with the students, try to find answers to their problems when possible. This is because some platforms, social networking, or apps were not accessible for blind people as they claimed to be, or were planned to be. Finally, Oliveira advocated that Information and Communication Technologies could assist the visually-impaired to learn an additional language.

Lúcio aimed to investigate the role of podcasts in English language learning by visually-impaired students, who were participants of the "Basic English for visually-impaired students" course at the Federal University of Technology-Paraná [46]. Based on the concepts of digital literacy, multiliteracies, Vygotskian's social interactionism and social representations, and also on a literature review found on the use of podcasts in the foreign language teaching-learning process, Lúcio conducted qualitative research and thus, collected data, observed classes, applied questionnaires and interviews, from February to June 2015. The results demonstrated that, when visually-impaired students used podcasts to study, their target language learning process was significantly affected. From passive recipients, they became active agents in the design, redesign, and appropriation of meaning, signification, and knowledge. She concluded that podcasts are very important resources in English language learning for visually-impaired people, as they allow these students to learn a language in an active, dynamic, interactive, inclusive, and critical way.

Still related to the use of podcasts and the teaching of the visually impaired Delgado et al., from Mexico, reported on a study that showed how podcasts can be incorporated as a teaching tool for visually-impaired elementary school students [47]. For this purpose, the context of the study was analyzed. Then, methodologies and teaching strategies were used by teachers. The curriculum was adapted according to the special educational needs of the students in question. This piece of research contributed to the improvement of the teaching-learning process, through the design of specialized podcasts, including an evaluation to assess its scope and limitations, and to offer teachers an educational view, which enables them to find contributions to methods, strategies, and sound resources for teaching.

While not specifically related to visually-impaired students, but on the issue of the use of mobile phones in foreign/second-language learning environments with other scenarios and contexts, Burston, from Cyprus, conducted a thorough and broad investigation of MALL, in which references to publications from other parts of the world can be found [48]. He searched for publications in professional journals, conference proceedings, project reports, and academic dissertations, from 1994 to 2012, and found 345 in total. His objective was to enhance the information contained in the references, and he offered a brief ( $~ 80$ word) summary of $90 \%$ of the references. This researcher also identified the country of origin of the study, native language (L1) and/or the second or foreign language (L2) involved, the mobile technology used, the learning area(s) targeted, the type of learners, their numbers, the duration of the study, and a summary of the results (i.e., learning outcomes and survey opinions). 
Although one can find a reasonable number of publications in the field of MALL, very few of them can be encountered when it comes to the use of MALL for inclusive education, specifically for the visually impaired. Therefore, there is a growing need for programs and research in this area of study, and, for this reason, this study is relevant.

\section{Research Design}

The methodology applied in this investigation is based on qualitative, ethnographic approaches to the analysis of teacher/student and student/student interactions inside and out the classroom.

Since our scenario is a foreign language inclusive classroom, we decided to resort to classroom ethnography. According to Watson-Gegeo, "classroom ethnography refers to the application of ethnographic and socio-linguistic or discourse analytic research methods to the study of behavior, activities, interaction, and discourse in formal and semi-formal educational settings such as school classrooms, adult education programs, and day-care centers" [49] (p. 135).

Studies on classroom interactions from an ethnographic perspective perceive the classroom as a cultural setting with its own norms of behavior. Our focus is on uncovering the spoken (and also often unspoken) norms of behavior that need to be internalized in order to be a successful learner of a foreign language using ICT. In this sense, the researcher and the participants conducted the investigation through the use of classroom observations, podcasts, and written exercises prepared in Google Form (Google, Inc.); two questionnaires were used, one applied at the beginning of 2014 and the other at the end of 2014. The interpretations of emergent discussions were framed by the theoretical concepts this study covers.

In relation to the data analysis approach, we resorted to descriptive and interpretive analyses for the reason that we intended to find linguistic and behavioral patterns concerning the use of ICT, focusing on smartphones, for communication and learning English.

\subsection{Context of the Study}

The Project "English for Us" was conceived of in 2014, by a research group called "Assistive Technology in the Teaching of Additional Languages to the Blind and the Visually Impaired" from the Academic Department of Foreign Languages at the Federal University of Technology-Paraná, in Curitiba-Paraná, Brazil, and was concluded in December 2016.

\subsubsection{The Scenario}

The project "English for Us" was developed in order to meet the growing demand of disabled people willing to learn the English language. Ten undergraduate students, majoring in the Portuguese and English Language and Literature Teacher Education Course, helped the professor/researcher plan and design the syllabus, along with didactic materials, for the course. Each undergraduate student sat with two blind or low-vision students in small groups and taught/studied the content of each unit using tailor-made didactic materials (produced and delivered via smartphones and the classroom).

\subsubsection{The Participants}

The students involved in the project, twelve blind and three low-vision students, were members of the Visually Impaired Association of Paraná (http:/ /www.adevipar.com/) and/or the Blind Institute of Paraná (http:/ /institutoparanaensedecegos-ipc.blogspot.com.br/). Their ages ranged from nineteen to fifty-four. There were nine men and six women. They all came from low and middle class families. In relation to their educational backgrounds, four had high school degrees and two were still in high school. The older ones (four of them), over 40 years of age, lived in the Blind Institute of Curitiba, 
from the age of 7 to 18 , where they had a special school education: ${ }^{1}$ from elementary up to high school. The remaining students had special tutoring at the Blind Institute of Curitiba or the Visually Impaired Association of Paraná for a part of the day and then went to regular schools for the other part. Nine of them had undergraduate degrees and nine of them worked. In relation to their proficiencies, two of them had studied English at language institutes for two years and could speak a little. The remaining students had never studied the language to speak it, although they had had six years of the subject in junior and high schools; these students knew very little English.

These visually-impaired students enrolled in our course for various reasons: one of them worked at a multinational company and wanted a promotion, which she would be eligible for if she spoke the language. Two of them were planning to become Tour Guides ${ }^{2}$ in the city of Curitiba, and, therefore, needed to know how to speak the language. One of them, who was still experiencing low vision (gradually becoming completely blind), wanted to become a professional writer, and wanted to learn about English-speaking writers. Today, after learning English with us for three years, he translates E.E. Cummings' poems to Portuguese for his blog (http:/ / faroesteliterario.com.br) and Facebook page. The remaining students said they wanted to talk to foreign people from over the world because since they would never be able to travel abroad, they wanted the world to come to them via World Wide Web. Most of them wanted to understand the lyrics of songs they sang, and two of them wanted to listen to an audio Bible in English on their smartphones.

Most of them became blind in early childhood. One student had a domestic accident and became blind at the age of six. Eight had health problems during their lives and lost their vision, which forced them to learn Braille at an early age. Three of them are gradually becoming blind but are still able to read large fonts. Three other students became blind in the last three years and have not yet been able to learn Braille.

Prior to their participation in the study, the students were informed about the purpose and procedures of the project and they provided their verbal consent.

\subsection{Data Collection}

This section is divided into three subsections, each one of them corresponding to a different instrument for collecting data: classroom observations, didactic materials on apps, as well as two questionnaires.

\subsubsection{Classroom Observations}

During classes, the undergraduate students, as well as the professor, would keep notes about their students' strengths and weaknesses, their difficulties, and regarding their knowledge of English and ICT, with a strong focus on smartphones.

\subsubsection{Didactic Materials on Apps}

Podcasts with drills, grammar explanations, and exercises (recorded in audio and in a written form) were elaborated, recorded and/or written, and posted in two groups: WhatsApp and in a closed Facebook group. The podcasts were recorded on a smartphone app, and the written exercises were made either using Google Forms or on a smartphone app, such as Polaris Office, and were posted to the two groups described above. We also used Google Drive (Google, Inc.) to store and share written exercises and podcasts with the student.

1 Up to the 1990s the Blind Institute of Curitiba offered regular schooling, from 1 grade up to 3rd year of high school, for blind students only. From the mid 1990s onwards, these students have been transferred to regular schools. However, IPC continues offering supplementary classes specially mathematics and writing.

2 Although these two students are blind, they show keen interest in becoming a tour guides, which was a great surprise to everyone in the group, once we suppose that one needs sight to be a guide. 


\subsubsection{Questionnaires}

Two questionnaires were created for the blind and low-vision students who were introduced to the study and gave verbal consent. The first was applied at the beginning of the course, 2014, in order to map the students' profiles and to also try and understand what the best procedures to take in order to conduct classes were. We also wanted to know which would be the most suitable approach to use in class. The questions inquired on students' age, study level, modality of study-if they studied in the private or public school systems, at home, with tutors, regular schools or special schools, if they were born blind or visually impaired or if they became blind afterwards, if they used Braille or ICT in their daily lives, if they had had experience with English learning, and thoughts on what would be the best ways to learn English.

The second questionnaire, based on the studies of Oliveira [44], was designed to investigate how students were perceiving and using ICT, which were offered to learn English during 2014. This questionnaire was applied at the end of 2014.

The questions included inquiries about their digital habits to study English outside the classroom. We were interested in knowing if they used Facebook, how often they did, if they had accessed one of the closed groups suggested, and if they had downloaded audio that had been posted to the closed group, created for them, and if they used Facebook on a computer or smartphone. In addition, there were questions regarding the use of podcasts, recorded by the teaching team, which were made available on WhatsApp, and how learners perceived the study of audio outside of the classroom. Other questions were related to which ICT was more available for them, if they had any difficulties when using the ICT suggested, if they had any ICTs to suggest for use in the next term, and learners' opinions of the course in general.

\section{Making Sense of the Data}

This study was designed for the purpose of investigating how we could associate the use of smartphones in the learning of English as an additional language to blind students. To begin our study, we resorted to Vygotsky's theory on dysontogenesis, which "implies a favorable social vision of children with disabilities and which stresses the need to strengthen and empower the individual skills instead of stressing the weaknesses, difficulties and deviations of such students" [26] (p. 4). From this concept, we decided to focus our research on two senses: hearing and touch.

The focus of our classes relied on hearing and touch, and, for this reason, the first and second specific objectives- the search for new applications for smartphones that could be used for teaching English, and to investigate how blind students use smartphones to communicate and learn English - were achieved by collecting data from two questionnaires and from some class observations written using our smartphone memos from students' comments from class. The choice of resorting to smartphone apps was based on UNESCO's recommendation, which advocates that "thanks to the integration of text-enlargement, voice-transcription, location-aware and text-to-speech technologies mobile devices can dramatically improve the learning of students with physical disabilities" [28] (p. 23). Thus, we wanted to know the profile(s) of students, with respect to level of education, profession, proficiency in the English language, as well as to have an idea of which ICTs were being used by visually-impaired students. We found out that eleven of the fifteen students (73\%) already knew how to use computers and laptops with the help of screen readers, such as DOSVOX [40], NVDA [41], and JAWS [42]. Four of them had no access to this type of technology. However, at the end of the first year of our English classes, everyone had received laptops and had quickly learned how to use them. In order to communicate, eleven students had smartphones and four did not. Out of the eleven who had smartphones, four had iPhones (Apple, Inc.), one had a Samsung Android phone (Samsung, Seoul, South Korea), and the remaining six used Nokia E5s (Nokia Corporation, Espoo, Finland). In the third semester of the course, all students who did not have a mobile phone, or who had a Nokia E5, either bought or received (as a donation) a smartphone. One student used his personal tablet (Samsung). All of them were given an mp3 device to verify if it was a good option for use as a teaching tool. 
All visually-impaired students said that the device was impractical as there was no screen reader and, therefore, they were not able to search for podcasts. Thus, mp3 players were removed from our scope. All students carried personal flash drives, and brought them to class at the beginning of our course, so that we could copy podcasts from laptops to the flash drives. At the beginning of 2015, when everyone had a smartphone, we used Bluetooth to transfer the podcasts-which were planned and recorded by the undergraduate students-from our smartphones to theirs, and, finally, in the middle of 2015, we opened the "English for Us" group on Facebook and created a WhatsApp group and sent the files via these groups. Thus, these latter procedures helped our students to retrieve the posts-podcasts and written materials-and practice them at any time, at home or at work, repeating them as many times as they wanted to and needed; hence, following UNESCO's beneficial reasons for using mobile learning [28] (pp. 9-28).

A brief historical perspective of the course and the group will be given so as to show how the use of ICT, specifically the smartphone, contributed to the enhancement of our visually-impaired students' ability to learn English as an additional language.

During our first classes, there were twenty-five visually-impaired students. In July 2015, there were fifteen students; ten had given the course up for various reasons. Of these fifteen remaining students, only nine of them read and wrote Braille. The other three students relied solely on their sense of hearing. The three low-vision students also preferred podcasts to the dozens of handouts with a large 50-point font.

Another element that guided our teachings was Vygotsky's idea that "the disabled tend to have a particular need for 'adaptations'" [26] (p. 11) "and that the adapted educational environment can provide the necessary conditions, and thus, learning" [26] (p. 11). From this moment on, we were aware that we would have to resort to technological resources, converging on the orientations of the Salamanca Statement [3], in order to make the course feasible and to facilitate communication between and among professor/researcher, sighted undergraduate and visually-impaired students, as well as to create a favorable environment for these students to learn the English language.

The application of the second questionnaire identified that eight of the visually-impaired students had access to the Internet at home, and they could access the podcasts and other assignments from class that we posted on the Facebook and WhatsApp groups. One of them went to the Visually Impaired Association of Paraná, daily, to access these groups. The tenth student, after a year of coming to our course, decided to share her neighbor's Internet. The five remaining students went to a relative or friend's home to have access to the Internet, and, therefore, were able to listen to the podcasts of the groups. Only the nine students who worked or had Internet at home accessed it several times a day, and every day. The remaining students depended on the availability of their relatives or friends. They said that they could access the Internet at least once or twice a week. Seven students did not have a Facebook account, and only four of them had downloaded and used WhatsApp regularly. Therefore, the undergraduate students opened Facebook accounts for those who did not have one, and downloaded the WhatsApp app for students who did not know about it. These visually-impaired students were taught how to use both the social networking platforms, and, later on, the instant messaging app. Today, after learning in our course, all of them use WhatsApp and Facebook. One of the low-vision students used Instagram (Instagram, Inc., San Francisco, CA, USA) and Twitter (Twitter, Inc., San Francisco, CA, USA), and accessed them weekly. A second student said he had a Twitter account, but rarely accessed it. At the beginning of 2015, two students listened to online newspapers, thirteen had e-mail accounts, and seven knew how to use Skype (Skype Communications Sarl, Luxembourg, Luxembourg) on their PCs (in 2017, we will teach them how to use Skype on smartphones and suggest speaking activities in English). At the end of 2015, one started his own blog, one began to access other people's blogs, and two of them downloaded the Audio Bible in English on their smartphones and listen to it daily. Here, we may perceive that the entire process of digital inclusion converges on what Kukulska-Hulme et al. claim that MALL may offer to students, such as 
"create and share multimodal texts, communicate spontaneously with people anywhere in the world, construct artefacts and share them with others" [37] (p. 3).

From the very beginning of our project "English for Us", we were aware that we would have to look for ICT, as well as assistive technology that could assist us in our teaching. Therefore, the undergraduate students and I had to learn how to use screen readers, such as DOSVOX [40], NVDA [41], and JAWS [42], for PCs. From the moment we knew how to use them, we decided to start offering exercises and didactic materials via Edmodo, which is also available as an app. After our first posts, we soon discovered, through classroom observations, that screen readers, for computers and apps, were not compatible with this type of VLE. We assumed we would face the same problems with Moodle, thus, we inquired to the students about this kind of VLE; two of them confirmed that we would encounter the same problems with Moodle, both in the computer and app versions.

This third objective was challenging and was instigated as we were trying to "reconceptualize" [37] (p. 3), not only new ways to deliver our teachings, and, thus, "build new communities of learners" [28] (p. 17), as well as offer "simultaneity of place" [29] (p. 151), but also new ideas on how to use mobile phones to "facilitate personalized learning", "enable our visually-impaired students to retrieve and study the content anytime, anywhere", and, most importantly, "assist our learners with visual disabilities" [28] (pp. 12-23) .

The aim of the group was to conceive of ways of learning that could "result in mental development and trigger various processes of development that would otherwise be impossible to happen" [25] (p. 24). Vygostky's term "mediation" was our key concept to put into practice in order for our interactions to take place and to allow these students proper learning conditions [25] (p. 15).

After applying the second questionnaire, we noticed that many visually-impaired students used social networks, and many of them had accounts on Facebook. Thus, the teaching group decided to motivate the five remaining students who were not on Facebook to create an account; from then on, we started to post podcasts and written grammar exercises to a closed group_- English for Us"- that researcher 1 organized for them and that worked as an extension of classroom activities. This was also a space in which undergraduate students regularly posted activities for each unit, so that students could do the exercises and send them back for corrections.

The teaching group started using Facebook as a teaching tool because we were aware that, since some of the visually-impaired students knew how to use this social networking website for communication, we would be able to help them "build and rebuild new knowledge" and, thus, learn the English language [15] (p. 5).

We also wanted to take advantage of the fact that most of the visually-impaired students personally knew each other, and that one constantly helped another spontaneously. We knew that the students who did not know how to use Facebook would either be taught by the other members of the group or learn it by themselves, i.e., we were aware that they would have their potential knowledge of using a social networking website to communicate and learn a language developed with the guidance and collaboration of "more capable companions" [25] (p. 24).

Presently, the Facebook closed group has fifty-eight members, including visually-impaired students, undergraduate students, former undergraduate students, colleague researchers, and the professor/researcher of the group. At the end of 2015, five students accessed their Facebook account (either on PCs, laptops, or smartphones) daily; the remaining students access it at least once a week, depending on the availability of an Internet connection.

Again, through classroom observations and informal talks with our students, they reported that they used the mobile version of Facebook (http://m.facebook.com) on their PCs because screen readers can easily read the posts. The ones who already had smartphones also emphasized that they opened Facebook on their phones because the screen readers on their phones were very efficient. From this moment on, some of them started posting to our group messages in Portuguese and also in English. 
Mediation and knowledge sharing between and among professor/researcher, sighted undergraduate students, as well as the visually-impaired students in the digital world (and in the English language) were common practices from the very beginning.

In addition to the page on Facebook, we decided to invite the visually-impaired students to participate in an open public group called "Blind and Visually Impaired People", where most of the posts were in English. This is a group of 1464 members from all over the world, with the majority being North American residents. The intention of this invitation was to offer our students real-life social practice using the English Language. The following examples, from Figures 1-5, of interactions among visually-impaired people and our students, using the mobile version of Facebook, were all borrowed from Oliveira's undergraduate final paper, ${ }^{3}$ who gave her written consent to reproduce them [44] (pp. 48-51).

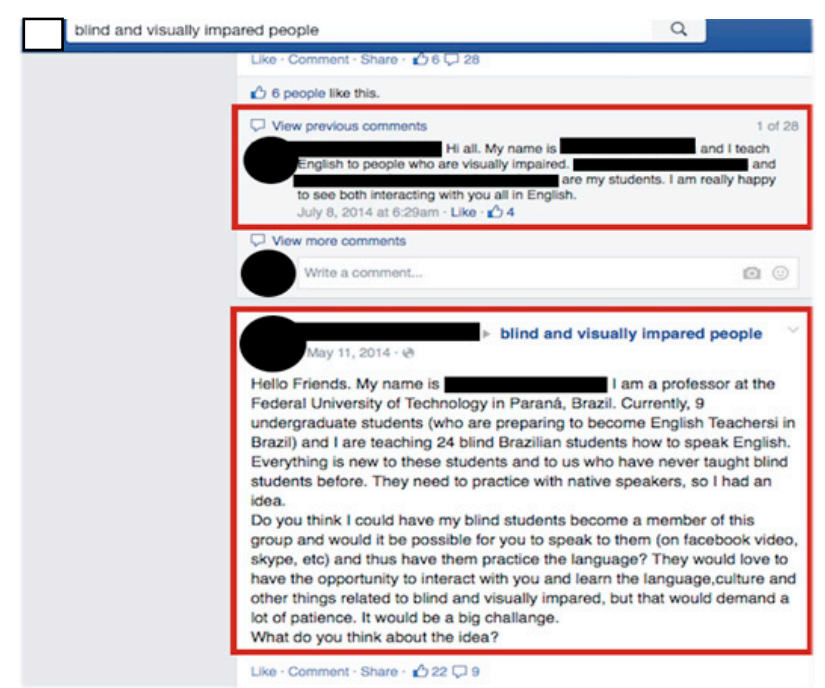

Figure 1. Professor/researcher asking if students could become members of a group. Retrieved from [44] with permission.

In Figure 1, the professor is asking if her students could become members of the group "Blind and Visually Impaired People". This was an attempt to have them engage in real-life communication. We intended to put into practice what Cope and Kalantzis advocate in their multiliteracies paradigm, i.e., that "new teachers" should design learning environments rather than just deliver content, providing learners with opportunities to use new media, and to use new media for learning [18]. Thus, in this case, our students were able to access the environment at any time and from any place, including from their smartphones, as suggested by UNESCO [28], Traxler [29], and Laurillard [30]. One blind student—Student A-presented themselves to the group, and even started conversations with other users, as we can see in Figures 2 and 3:

3 In Brazil, in order for a student to be eligible for graduation, his/her undergraduate final paper is evaluated by a board of three professors like a Master's defense. 


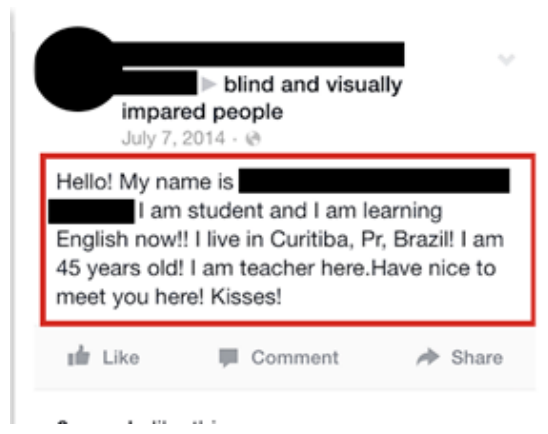

Figure 2. Student A presenting themselves to the "Blind and Visually Impaired People" Facebook group. Retrieved from [44] with permission.

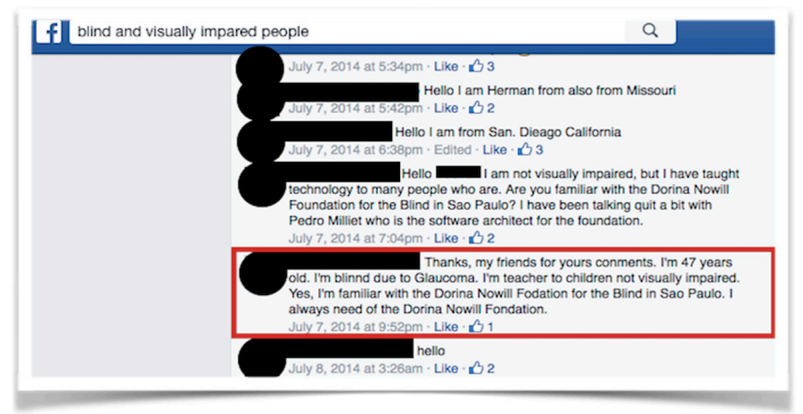

Figure 3. Student A thanking replies. Retrieved from [44] with permission.

Figure 4 shows that, on the same day that Student A posted on the "Blind and Visually Impaired People" group on Facebook, their spouse—student B—also presented themselves:

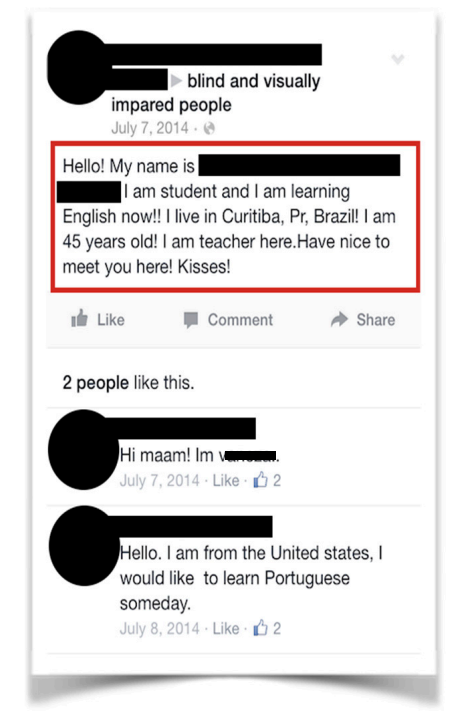

Figure 4. Student B presents themselves to the group. Retrieved from [44] with permission.

The professor/researcher's comment on the post, in both languages, demonstrates satisfaction with the students communicating in the target language, as shown in Figure 5: 


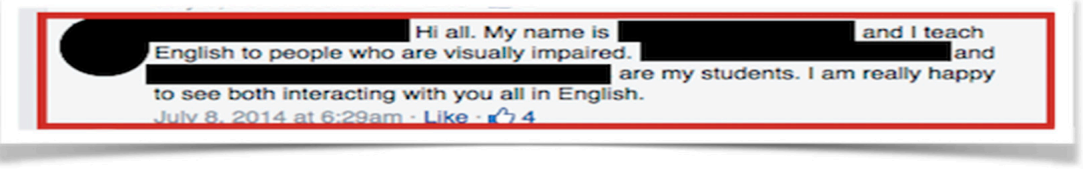

Figure 5. Professor/researcher praising students in the target language. Retrieved from [44] with permission.

Oliveira [44] had already noted that, with the previous figures, it is possible to perceive that, by offering students this multimodal opportunity to communicate [18], the professor/researcher managed to have his/her students use the English language in a natural digital environment, and also made it possible for them to take responsibility for their learning, as well as to continue their learning, independently and beyond formal lessons and the classroom.

Right after the interactions on Facebook described above, Students A and B decided, spontaneously, to have a Skype conference in English with someone that they had met in the "Blind and Visually Impaired" group. Soon after their talk, Student B posted an audio to WhatsApp in order to tell us about the conversation that they and their partner had had with a blind American girl. They were very enthusiastic about having achieved such a feat. The transcription of the audio post, which follows, has not been corrected in order to be reliable to this student's language performance.

Teacher X, this is B from the English course. Sorry to bother you on a Saturday afternoon, but I'm here extremely excited. I have just talked to my America friend from the United States by Skype. It was a mess. But we could understand each other. 'A' spoke a little bit too. Most of it was in English, because it is easier for me, but we spoke a little in Spanish. [...]. It was an amazing experience, very nice. This course is worth a thousand [sic]. I just want to thank you for all the opportunities, the tips, the effort you've been having with us, and the willingness, OK? [...] God bless you, thank you. ('B', English learner by Skype). (translated by the WhatsApp receiver) [44] (p. 51).

This event again shows that these two students had real-life interactions in the English Language using an ICT, their smartphones, confirming the rationale behind the multiliteracies paradigm, i.e., these students "surpassed their barrier and made essential their auditory [ ... ] construction and reconstruction of these meanings and directions" [18] (p. 191). They also socially recognized a different way of engaging in new digital social practices [15] (p. 3). In terms of foreign language learning, they "broadened their understanding of who they are in relation to the other when communicating in a foreign language (identity-otherness relation) and enriched their perspectives on plurality, diversity and multiplicity present in today's society" [21] (pp. 45-46). Finally, according to UNESCO [28], these new ways of social interaction, helped them to "expand the reach and equity of education", "bridge formal and informal learning", and also enhanced their motivation, as claimed by Laurillard [30] (p. 156).

In the second semester of 2014, our visually-impaired students asked us to open a group on WhatsApp. Therefore, converging on Laknshear and Knobel's concepts of digital literacies [15] (p. 5), we wanted our students to engage in the construction of meanings mediated though digital coding, thus, as soon as our blind student asked us to consider using WhatsApp, on 7 December, we started an "English for Us" group on WhatsApp.

From then on, we started talking about everyday issues and sending them two types of homework assignments: Written grammar activities (in Word and in PDF format) and podcasts with an explanation of the grammar topics and conversation drills. Table 1 shows an example of a podcasts, sent over the WhatsApp group, "English for Us": 
Table 1. Transcript 1: Social Practice 1.

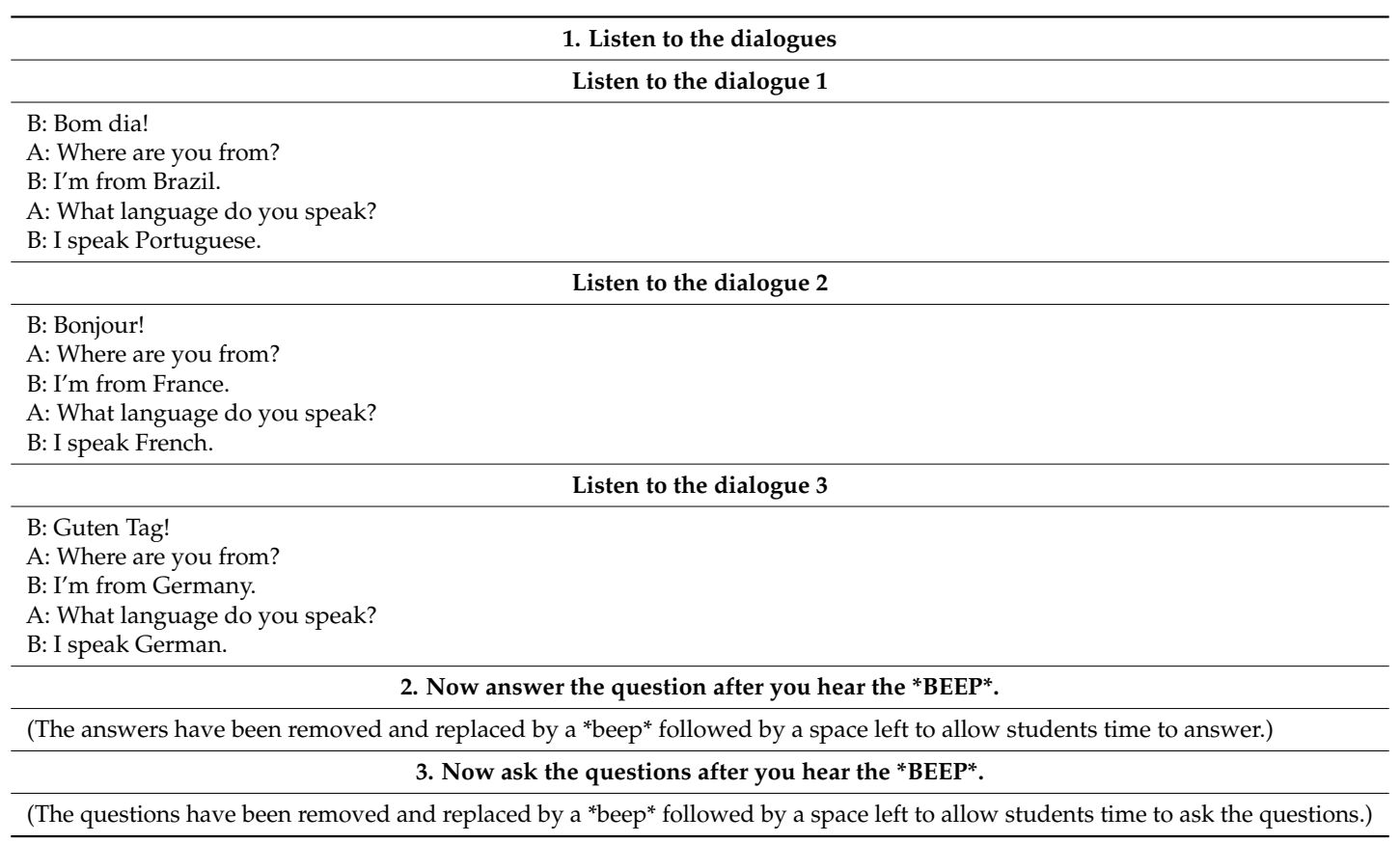

Every day, some of the blind students sent us messages in English on the WhatsApp group. Many students posted a "Happy Friends Day" greetings on 21 July 2015, as shown in Table 2.

Table 2. Transcript 2: Happy Friends Day greetings.

English for Us Group

A podcast of one of the blind students:

"Hi everyone. I wish you all a happy friend's day. God bless you all."

Another blind student answers: "Thank you X"

A undergraduate student answers: "Thanks, X! Happy friend's day, everyone."

A second blind student answers: “Ieee!!! Thank you X. And happy friend's day everyone."

All members of the group gave oral consent to reproduce this conversation from WhatsApp group.

After each class, we would provide our students a song that would either contain vocabulary or grammar items that had been taught that day. On the following day, we would post the songs as podcasts, and the lyrics were written as texts on WhatsApp or Facebook groups. The visually-impaired students asked the teaching team to send them the audio files of the songs. Most of them sang the songs until they knew them by heart. Occasionally, when the posts were delayed, students would post audio asking for the songs. We offered songs via this digital coding because we aimed at helping our students develop their English, but, at the same time, 'expand their worldview and critical perception' of different rhythms, lyrics, and lifestyles, converging on what Mor advocated [21] (p. 47). Table 3 shows a typical American children's song, and a blind student commenting on how he liked it, with a post in Portuguese and English.

Two-way learning was the tone in our classes through mediation [25] (p. 24). For example, one of the low-vision students, Student $C$, taught researcher 1 and the undergraduate students how to use WhatsApp Web, which is a web version of the original free phone app in March 2015. At the end of 2015, all students accessed WhatsApp either daily or two to three times a week.

In the second semester of 2014 and the first of 2015, during some classes, our visually-impaired students told us that they were having difficulties in opening the Word and PDF files and were doing their assignments on the WhatsApp and Facebook groups. 
The teaching group got together to discuss about our students' difficulties and problems. We resorted to Monte Mor [21] (pp. 47-48) and took into account the heterogeneity of language levels in the classroom, as well as the diversity of our students' backgrounds, social classes, and health problems: Many of them have other pathologies in addition to blindness, such as schizophrenia, deafness, hematological illnesses, and diabetes. Therefore, because of these difficulties, some students were facing challenges while using some apps on their mobile phones; because four of them had recently received smartphones as donations, the group decided to organize a two-Saturday workshop, on 20 and 27 June 2015, entitled Smart Teaching, Smart Learning: Using the mobile to teach/learn an additional language. Our general objective was to teach undergraduate sighted students, as well as visually-impaired students, to use some mobile phone apps together with the PC interface and how to turn these mobile phones into multi-modal platforms for teaching and learning an AL. We wanted to broaden our students' perspectives of digital literacies and, thus, help them build up their language repertoire in multimodal ways, making the auditory and tactile needs essential [17-20].

Table 3. Transcript 3: Song posted on Facebook—“English for Us” closed group.

\begin{tabular}{|c|}
\hline $\begin{array}{l}\text { Musiquinha que será cantada na próxima aula. Adivinhem o que iremos aprender na aula? } \\
\text { ('A song we will sing in the next class. Guess what we are going to learn in class?') }\end{array}$ \\
\hline An upload of the song "I am a Pizza". \\
\hline Too many peperoni. Teacher. Gostei do ritmo ('I liked the rhythm') \\
\hline
\end{tabular}

The specific objectives of the workshops were to show these students some smartphones apps and to teach them how to use them; to look for new phones apps that could be used for teaching/learning languages; to investigate how undergraduate sighted students in pre-service teaching could use these apps to prepare and manage additional language classes; and, finally, to examine how blind students use the apps to communicate and learn an AL.

During the workshop, we were able to teach the students how to use Google Drive and Google Docs on smartphones. We also taught them how to use Google Drive and Google Docs on a PC, and how the interface between them occurs, i.e., how they could do the exercises proposed by the teacher on Google Drive and do them either on their smartphones or on a PC.

We prepared a grammar exercise on Google Forms and sent it to them; however, we had a great deal of difficulties related to answering multiple-choice exercises. The first problem was that screen readers do not read parentheses. We had to adapt the exercise and substitute parentheses with the word 'alternative'. We also found out that we had to write the word 'blank' where the students were supposed to insert the correct answer, because the screen readers would skip the gap where they were supposed to answer and, therefore, they did not know where in the sentence they had to put the correct word. Figure 6 shows how we adapted, for blind students, a multiple-choice exercise created on Google Forms and posted on Google Drive.

The second problem that these students faced while trying to answer the exercises on their smartphones was that they were not familiar with multiple-choice exercises and, therefore, they had to scroll their fingers up and down the screen, looking for alternatives, and going over them several times so that they could find and choose the correct alternative. Most of them had a very hard time trying to adapt to this kind of exercise on a mobile phone. 


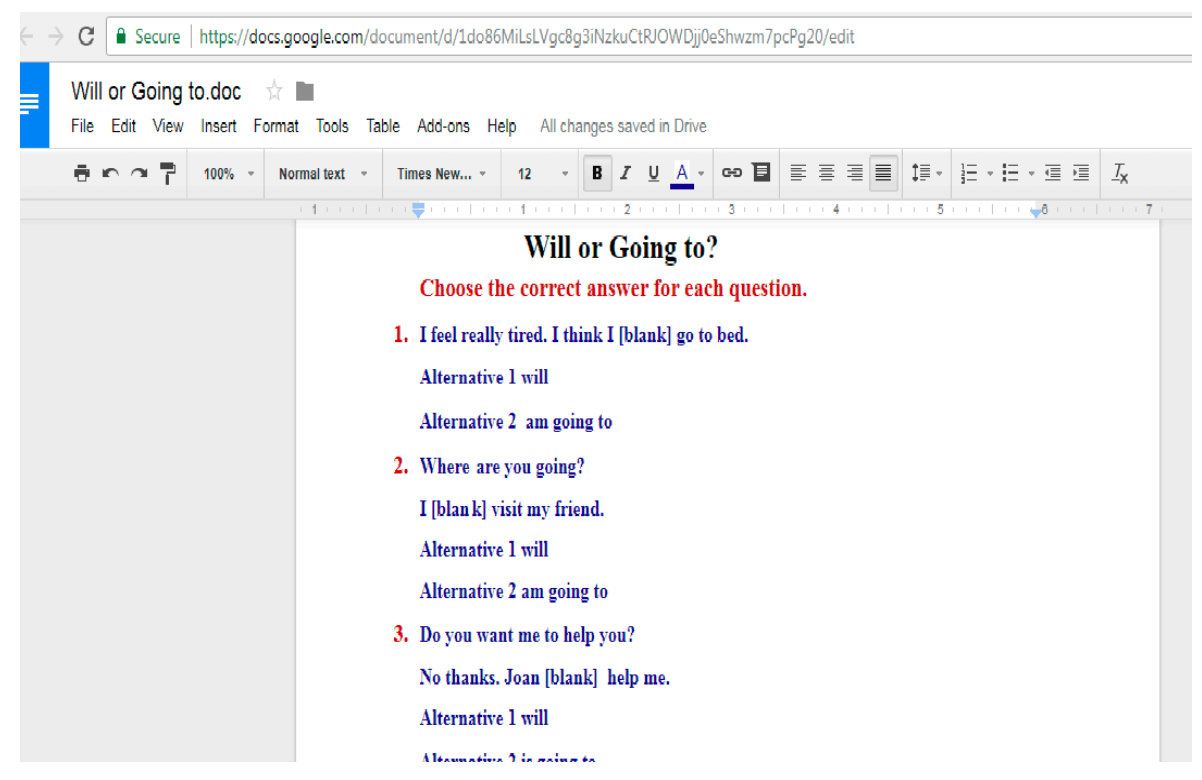

Figure 6. Adapted multiple-choice grammar exercise on Google Forms. Exercise conceived and written by Retorta.

A third problem was that students would set their TalkBack or OverVoice to Portuguese and, when doing the exercise in English, the words read out loud sounded incomprehensible due to the strong Portuguese accent of the English words. We are unaware of any screen reader program that switches languages automatically when the words of each language are read out loud.

Finally, our students had difficulties understanding the concept of "Cloud". Before showing them how to use Google Drive on a smartphone, we first opened everyone's Gmail accounts to teach them what Google Drive was and how to use it. The visually-impaired students quickly taught the sighted members of the group that they used a simple version of Gmail, because the screen reader only read words, and not icons, and, therefore, the simple version of Gmail was much more compatible with screen readers.

After teaching them how to use Google Drive on PCs, we resorted to the smartphones. At the end of the workshop, half of the group still could not use Google Drive on their smartphones. In this case, their visual impairment hindered the learning process under the mediation of guidance, as advocated by Vygotsky [25]. The experience we had during the workshops showed us that it is a large challenge to offer students with visual impairments new forms of digital coding, and, thus, new social practices in order to engage in the construction of meanings, as claimed by Lanksheir and Knobel [15] (p. 5). Six hours of the workshop was not enough to teach them how to use all the interesting apps and programs with their interface using PCs.

Future courses will be planned and organized to expand our knowledge and expertise on using apps for learning and teaching additional languages.

As soon as the workshop was over, a professor from the Design Department of the Federal University of Technology-Paraná kindly prepared a completion certificate for the students. Figure 7 shows certificates with a QR Code (abbreviated from Quick Response Code), so that the visually-impaired students could learn how to use QR Codes on their mobile phones in order to read out loud the content of the document. 


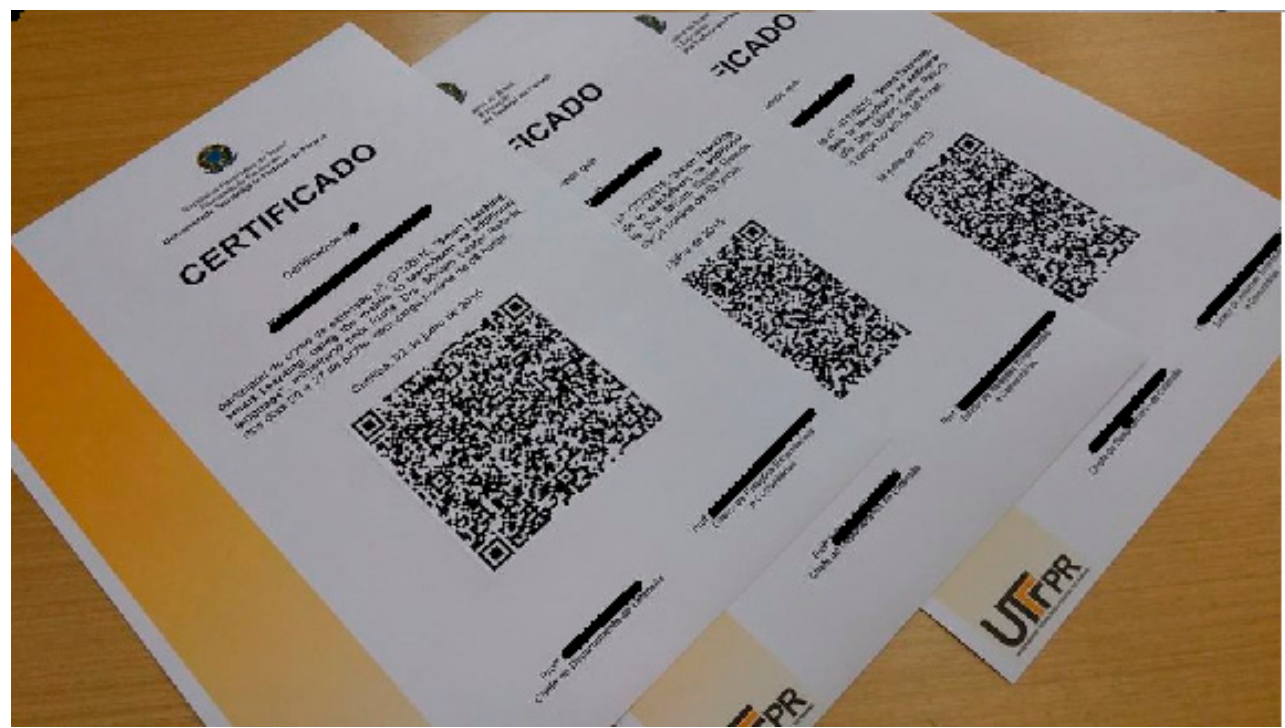

Figure 7. Official certificate of the workshop Smart Teaching, Smart Learning: Using the mobile to teach/learn an additional language.

Around the code was a high relief bar so that students could feel where the code was and place their mobile phone's barcode scanner accordingly. The phone scanner, with a screen reader, would read out the content of the certificate. Again, all the screen readers were set to read in Portuguese, so the words in English had a very strong American/English accent. Behind this simple document is a bigger intent: The visually-impaired students would, not only be engaged in 'a new scenario of mobile phone accessibility' because they had to learn how to use the QR Code app with the screen reader, but also "allow them to socialize, learn and work across multiple real-world settings", as claimed by Pegrum [27] (p. 15).

After the workshops had been given, and after all of us had learned how to teach and learn via smartphones and PCs during classes, we decided to work on the third and last specific objective of our study: Evaluate the learning process of using smartphone applications in order to learn English.

At the end of the first semester in 2015, the group had a final feedback day. Six students said that they accessed the groups at least three times a week to study the podcasts. The remaining students accessed the groups when they had access to the Internet. On this day, all the student could express how they felt, what they had learned, what they had not learned, and what they expected from the following semester. Student E sent us a WhatsApp message describing his feelings towards the use of smartphones for learning English. The transcription of the audio post, which follows, has not been corrected in order to be reliable to this student's language performance.

The feeling after this process was of fear, due to the lack of access and knowledge of technology; nervousness, about not knowing what to do; distress because it is a very expensive and newly-acquired device, and, above all, panic to imagine that I could lose my phone, because, for me, it is a working tool. A problem a sighted person normally solves using his/her car to go to the places and solve it on the spot, I can solve it, most of the time, over the phone. (Translated by the authors)

Of the fifteen visually-impaired students, only one student, who was in her 50s, was reluctant to use a smartphone. However, at the end of 2015, her peers convinced her that she would, not only learn English, but also, and mainly, never feel lonely again as all of them would send messages via WhatsApp on a daily basis.

In relation to their language achievements, in 2014, when the project started, only two students had studied English previously at languages institutes for more than 2 years. The remaining eight 
were real beginners, although, technically speaking, they had had English classes from 6th grade up to their senior year of high school.

At the end of each semester, these students were submitted to an oral test to evaluate how much they had learned during the periods. For each semester, the undergraduate students would set up goals for the visually impaired to achieve based on the recommendations of the Common European Framework of Reference for Languages (CERF).

Based on the oral exams, which were always recorded, we could observe that one of them, who had already had a previous three-year instruction before our course, improved. For instance, at the beginning of the course, this student could not use the present perfect tense, nor the 1st and 2nd conditionals and, at the end, he was fluently using these verbal structures. In the last Skype class, this student was evaluated and we could observe that he answered $90 \%$ of the questions correctly. According to his interactions in and outside the classroom, we can state that he was able to understand the main ideas in complex texts on concrete and abstract subjects. He was able to express himself in a clear and detailed manner on a wide variety of topics and to explain a point of view on a current theme, exposing the advantages and disadvantages of various possibilities. He was also able to communicate with a certain degree of spontaneity with native speakers, with eventual tension from part to part. This could be verified when this student started speaking to an American lady, who lives in Vancouver/Washington, via Skype on a weekly basis. He is teaching Portuguese to her and she is speaking English to him up to the present moment. His proficiency is compatible to a B1 level according to the CERF.

A second student, who had also had a two-year instruction of the English language before our course, improved her level of proficiency, however to a lower level according to the CERF. This student was able to understand the main issues, when she used clear and standardized language and the subjects were familiar to her (topics covered at work, at school and in leisure time, etc.). She was able to handle most of the everyday situations. She was able to produce a simple and coherent speech on subjects that were familiar or of personal interest. In the last oral test that we conducted, she was able to use the past tense along with the present perfect tense. She was also able to use the 1st conditional. Her proficiency level is compatible to the beginning of B1 according to the CERF.

Three of the visually-impaired students were able to understand isolated phrases and frequent expressions related to immediate priority areas (e.g., simple personal and family information, shopping, surroundings). They were able to communicate in simple tasks and in routines that required only a simple and direct exchange of information on subjects that were familiar and habitual to them. In their last oral test, they were able to talk about what they had done on the weekend, and also about some problems they were facing in terms of mobility due to their deficiency. Their proficiency level was compatible to an A2 according to the CERF. The example in Table 4 is a transcript of spontaneous speech of an audio posted by one of these students on the WhatsApp group called "English for Us" on 2 July 2017. 
Table 4. Transcript 4 .

$\mathrm{Hi}<\ldots>$. Thank you. You take me to dream again...// I ... I was very ...

ah eh mmh... unbelieve... /// I, I... I didn't ah eh... I wasn't ah eh mmh... how do I say... animada./// I ... I ah eh mmh... And you, suddenly, did me to dream again... To study English. Now I am studying Spanish too. And ah eh... and these things are very important to... to... to people ah eh retired. Aheh, we// ah eh// we sometimes, we retired, become unbelieve ah eh we think//ah eh we don't need to learn new things////and ah eh you... your really did me to dream again.
| hai <... // tænk ju | ju terkə mi: tu dri:m a'gen ...// ar I ar wəz veri ... // a: e $<m m h . .$. $<\wedge$ nbi'li:v> | aI | aI | aI didənt a: <eh ... i $>$ wa:zənt a: e $<$ mmh ... $>$ hav du ar $<$ ser ... $>$ $<$ animada $>$ | aा $\mid$ as a: e $<\mathrm{mmh}>\mid$ ənd ju $\mid$ sıdnḷ | did mi: tu dri:m ə'gen I tə st $\Lambda$ di ing,glif I nav ar əmə stıdirn spæni tu: | əndə a: e ... ənd ði:z Өinz ərə veri impo:rtəntə tu: | tu: | tə pi:pl a: e rə'tarrd | <aheh> | wi ... a: e... wi səm'tarmz | wi rə'tarrd | bı'kım < $<$ nbı'li:v> 'a: e wi tınk //a: e wi doont ni:də tu la:n nu: tinz ... əndə a: eh ju ... । jər rili did mi: tə dri:m a'gen l

Two of the students, who had more serious health problems, were still able to achieve a good level of proficiency, similar to the beginning of an A2, but were not as successful as the previous three. However, they achieved a score of more than $80 \%$ in a basic oral test. The transcript of one of the tests is reported in Table 5:

Table 5. Transcript 5.

\begin{tabular}{|c|c|}
\hline $\begin{array}{l}\text { Evaluator: What did you do last Saturday? } \\
\text { Student: I went to a shopping mall and bought } \\
\text { a pair of shoes. } \\
\text { Evaluator: What did you do on Sunday? } \\
\text { Student: I went to church and prayed. } \\
\text { Evaluator: What did you do yesterday? } \\
\text { Student: I went to the park to run. } \\
\text { Evaluator: Where did you go on your last } \\
\text { vacation? } \\
\text { Student: I went to the beach. } \\
\text { Evaluator: Where did you live when you were } \\
\text { a child? } \\
\text { Student: I lived in São Paulo. }\end{array}$ & 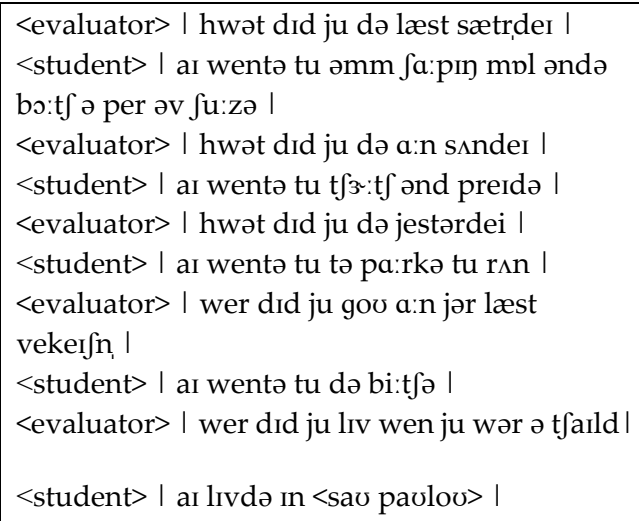 \\
\hline
\end{tabular}

The three remaining students, who were much younger, were able to understand, although with limitations, everyday language and familiar expressions as well as very simple statements. They were able to introduce themselves and ask questions and give answers about personal aspects such as where you live, the people you know and the things you own. Since it was their first contact with smartphones, they had to learn how to use this new device as well as learning the English Language. This might have been a limiting factor for them. An excerpt of an oral test follows (Table 6): 
Table 6. Transcript 6.

\begin{tabular}{|c|c|}
\hline Evaluator: What's your name? & $<$ evaluator> | wəts jər nerm | \\
\hline Student: My name is .......... & $<$ student $>$ | mai nermə $\mathrm{s}<\ldots \ldots \ldots .>$ | \\
\hline Evaluator: How old are you? & $<$ evaluator $>$ | hav ould or ju | \\
\hline Student: I'm 10 years old. & $<$ student $>$ | aimə ten jırz oøldə | \\
\hline Evaluator: Where do you live? & $<$ evaluator $>$ | wer də ju liv | \\
\hline Student: I live in Curitiba. & <student> | aı lıvə inə, kjøə ti:bə | \\
\hline Evaluator: What do you do? & $<$ evaluator $>$ | hwət də ju du: | \\
\hline Student: I am a student. & $<$ student $>$ | аı əmə ə stu:dəntə | \\
\hline Evaluator: Do you have any brothers or sisters? & $<$ evaluator>| də ju həv ənı br^ðrz ə:r sıstərz | \\
\hline Student: I have a twin brother. & $<$ student $>$ | aı həvə ə twinə brodə | \\
\hline
\end{tabular}

We plan to continue the project and apply a mock proficiency exam to verify whether they would be approved in the first proficiency exams according to the CERF, i.e., the Key English Test (KET) and the Preliminary English Test (PET). We also want to spend most of the time learning how to use smartphones in order to teach these students and to offer workshops so that they can become independent learners.

\section{Limitations of the Study}

We could have a clear idea of how much the real beginner students improved their English by the oral tests applied at the end of each semester. However, one of the most difficult problems to solve in this project was the evaluation of the students who had had formal instruction of the language before our course, i.e., their proficiency level in the language before and after our classes. There are some reasons why the assessment of overall proficiency has become a challenge. First, a mock proficiency exam should have been applied at the beginning and at the end of the course in order to find out how much English they actually learned during the course. However, we had two other problems to solve: we would have to print the whole exam in Braille (this meant many pages), for the students who read and wrote in Braille and, for the students who could not read nor write in Braille, the undergraduate students would have had to read the exam out loud to the visually-impaired students. We would also have had to find a way-maybe through a text editor on smartphones-to have them do the written parts of the exam. The process of doing a proficiency exam would take much more than 2 or $3 \mathrm{~h}$. The visually-impaired students stated that they take double the time, sometimes even more, to accomplish their school assignments through the use of Braille or with an external reader (who reads the whole assignment out loud). Therefore, due to these drawbacks, we have not had time to plan new strategies on how to apply international proficiency exams to them and thus, evaluate how much English they have learned according to an international framework. Although we have looked for adapted proficiency exams to apply to visually-impaired students, we have not found any exam specially developed for these kind of students.

Another problem is that most visually-impaired students have other diseases associated with their blindness, for example, diabetes, hematological diseases, schizophrenia and hearing disorders, and, for this reason, each one has his/her limitation(s). These various health disorder conditions make each visually-impaired student unique in the sense that each one has a different pace of learning the English language. We would never be able to achieve a homogeneous group in terms of language proficiency.

\section{Conclusions}

Visually-impaired citizens in Brazil have come a long way from when they were completely neglected and excluded from social interactions, to the current paradigm of inclusion. From the 1990s onwards, with the World Conference on Education for All [50] and the Salamanca Statement on 
Principles, Policy and Practice for People with Special Educational Needs [3], and the Convention of Guatemala [4], Brazil has been timidly crawling into the "era of inclusion", where the rights to social integration for people with disabilities have been demanded by the community, despite the fact that our society, as a whole, still has to endure and adapt to the differences $[8,9,51]$.

Our course, "English for Us", together with classroom ethnographic data collection and analysis, led us to some conclusions. First, we may say that our students, after our courses, were able to use some ICTs, specifically smartphones, to communicate in and learn English. Figures 1-5 and Figure 7 show how some of these students used Facebook and Table 2 is an example of how some used WhatsApp. All Figures 1-7 reveal how these students used the English language that they had just learned together with the ICTs.

Our classes, workshop, field trips, and individual tutoring have slowly helped these students improve their communication skills via ICT, and also learning of the English language. When they were exposed to the mobile apps and programs, they quickly learned and helped each other to adapt and solves their issues. Mediation and interaction among them was a key factor in the course. The interactions between and among the professor/researcher, sighted undergraduates, as well as the visually-impaired students showed a collective effort, one teaching the other, to make smartphones accessible and useful to all students. The blind students constantly asked our undergraduate students, via WhatsApp, for help to solve their phone-related problems and doubts.

Digital literacies, multiliteracies, and critical education, as advocated by Cope and Kalantzis [17-20], Lankshear and Knobel [14-16], and Monte Mor [21-23], are radically changing the way we teach, learn, interact, and view the world that surrounds us. The aim of our course, in the beginning, was to teach the English language to visually-impaired students. However, the heterogeneous group, with their different difficulties, skills, and objectives, forced us to focus on the multiliteracies paradigm. Our initial aim, which was teaching English, evolved to an emancipatory pedagogy [18] (p. 188) when we decided to help these individuals become included in society as citizens, offering them the world of a foreign language and culture, together with a new world of digital and multiliteracies. Our desire was to empower them so that they can change their own lives and the lives of other visually-impaired Brazilians.

Slowly, but steadily, our students have been able to use new media to learn the English language from their homes, work, or school. They were also more aware of their own responsibility in learning. Our classes have been a scenario for collaborative and sharing teaching/learning experiences. Some of the students have started using the English language in foreign virtual communities, which shows that they have been using the language for actual social practices and which also shows that they are learning independently of our classes and lessons.

ICTs, more specifically smartphones, are radically transforming how we access our shared knowledge sources by keeping us constantly connected to near-infinite volumes of data and information. The project revealed that both undergraduate and visually-impaired students were taken by a sense of self-determination, collective collaboration, and personal development. Through the use of smartphones and their interface with PCs and laptops, we could determine that it is totally feasible to teach visual-impaired people to speak English.

Currently, this project has evolved to total virtual teaching and learning via Skype. Thirteen visually-impaired students are being taught, on a weekly basis, by thirteen undergraduate students: each blind student has been paired up with one undergraduate student. Data is being collected, and by the end of this year, we will be able to evaluate how this instant messaging app may become another virtual environment for teaching visually-impaired people the English language.

Acknowledgments: This article was conceived under the Research Project "Language and Society: Possibilities of Social Participation of Socially Vulnerable Groups Through the English Language", registered at the State University of Londrina (Londrina, Brazil), number 08581. Thanks to the Brazilian National Council for Scientific and Technological Development (CNPq) for the financial resource during the period of 1 March 2013 to 28 February 2016 related to the validity of the research productivity (PQ2) grant to the second author, case no. 311921/2012-4. 
Author Contributions: Miriam Sester Retorta conceived and designed the experiments; Miriam Sester Retorta performed the experiments; Vera Lúcia Lopes Cristovão and Miriam Sester Retorta analyzed the data; Vera Lúcia Lopes Cristovão and Miriam Sester Retorta wrote the paper.

Conflicts of Interest: The authors declare no conflicts of interest.

\section{References}

1. World Health Organization. Visual Impairment and Blindness. Available online: http://www.who.int/ mediacentre/factsheets/fs282/en/ (accessed on 11 October 2015).

2. United Nations. The Universal Declaration of Human Rights (1948); United Nations: New York, NY, USA, 2012.

3. The United Nations Educational, Scientific and Cultural Organization (UNESCO). The Salamanca Statement and Framework for Action on Special Needs Education; UNESCO: Paris, France, 1994.

4. Presidência da República do Brasil. Convenção Interamericana Para a Eliminação de Todas as Formas de Discriminação Contra as Pessoas Portadoras de Deficiência; DEC 3.956/2001; Brasilia, Brazil, 2001. Available online: http:/ / www.planalto.gov.br/ccivil_03/decreto/2001/d3956.htm (accessed on 11 October 2015).

5. Ministério da Educação. Programa Educação Inclusiva: Direito à Diversidade; MEC/SEESP: Brasilia, Brazil, 2007.

6. Ministério da Educação. Programa: Formação Continuada de Professores na Educação Especial; MEC/SEESP: Brasília, Brazil, 2009.

7. Ministério da Educação. Programa Implantação de Salas de Recursos Multifuncionais; MEC/SEESP: Brasília, Brazil, 2008.

8. Ministério da Educação. Estatuto Para Pessoas com Deficiência; Presidência da República: Casa Civil, Brazil, 2015.

9. Ministério da Educação. Diretrizes Nacionais Para a Educação Especial na Educação Básica; MEC/SEESP: Brasília, Brazil, 2001.

10. Ministério da Educação. Orientação e Mobilidade: Conhecimentos Básicos Para a Inclusão da Pessoa com Deficiência Visual; MEC/SEESP: Brasília, Brazil, 2003.

11. Ministério da Educação. Ensaios Pedagógicos: Construindo Escolas Inclusivas; MEC/SEESP: Brasília, Brazil, 2005.

12. Ministério da Educação. Saberes e Prática da Inclusão; MEC/SEESP: Brasília, Brazil, 2006.

13. Dantas, R. A proposta educacional inclusive: Aspectos da legislação. In Deficiência Visual e Ensino de Linguas Estrangeiras: Políticas, Formação e Ações Inclusivas; Medrado, B.P., Ed.; Pontes Editora: Campinas, Brazil, 2014; pp. 33-57.

14. Lankshear, C.; Knobel, M. Sampling "the new" in new literacies. New Lit. Sampl. 2007, 29, 1-24.

15. Lankshear, C.; Knobel, M. Introduction: Digital Literacies: Concepts, Policies and Practices. In Digital Literacies: Concepts, Policies and Practices; Lankshear, C., Knobel, M., Eds.; Peter Lang Publishing: New York, NY, USA, 2008; pp. 1-16.

16. Lankshear, C.; Knobel, M. New Literacies: Changing Knowledge and CIassroom Learning; Open University Press: Philadelphia, PA, USA, 2005.

17. Cope, B.; Kalantzis, M. Putting Multiliteracies to the Test. Newsletter of the Australian Literacy Educators' Association, February 2001.

18. Cope, B.; Kalantzis, M. Literacies; Cambrdige University Press: Cambridge, UK, 2012.

19. Cope, B.; Kalantzis, M. Designs for Learning. E-Learning 2004, 1, 56.

20. Cope, B.; Kalantzis, M. Multiliteracies: Literacy Learning and the Design of Social Futures; Routedge: London, UK, 2003.

21. Monte Mor, W. O ensino de línguas estrangeiras e a perspectiva dos letramentos. In Se Hace Caminho al Andar: Reflexões em Torno do Ensino de Espanhol na Escola; Barros, C.S., Costa, E.G., Eds.; Faculdade de Letras da UFMG: Belo Horizonte, Brazil, 2012; pp. 37-50.

22. Monte Mor, W. Multimodalidades e comunicação: Antigas novas questões no ensino de línguas estrangeiras. Let. Let. 2015, 26, 469-476.

23. Monte Mor, W. Critical literacies, meaning making and new epistemological perspectives. Matices en Leng. Extranj. 2008, 2, 1011-1177.

24. Vygotsky, L.S. The Fundamentals of Defectology (Abnormal Psychology and Learning Disabilities). In The Collected Works of LS Vygotsky; Rieber, R.W., Carton, A.S., Eds.; Springer: New York, NY, USA, 1993; Volume 2. 
25. Vigotski, L.S. A Formação Social da Mente: O Desenvolvimento dos Processos Psicológicos Superiores; Martins Fontes: São Paulo, Brazil, 2003.

26. Rodina, K.A. Vygotsky's Social Constructionist View on Disability: A Methodology for Inclusive Education. Presented at the European Learning Styles Information Network (ELSIN), University of Oslo, Oslo, Norway, June 2006. Available online: http://lchc.ucsd.edu/mca/Paper/VygotskyDisabilityEJSNE2007.pdf (accessed on 17 July 2017).

27. Pegrum, M. Mobile Learning: Languages, Literacies, and Culture; Palgrave Macmillan: London, UK, 2014.

28. West, M.; Vosloo, S. UNESCO Policy Guidelines for Mobile Learning; UNESCO: Paris, France, 2013.

29. Traxler, J. Students and mobile devices. ALTJ Res. Learn. Technol. 2010, 18, 149-160. [CrossRef]

30. Laurillard, D. Pedagogical forms of mobile learning: Framing research questions. In Mobile learning: Towards a Research Agenda; Pachler, N., Ed.; WLE Centre, IoE: London, UK, 2007; pp. 153-175.

31. Rheingold, H. Smart Mobs: The Next Social Revolution; Perseus Books Group: New York, NY, USA, 2002.

32. The Statistics Portal. Number of mobile phone users worldwide from 2013 to 2019 (in billions). Available online: https: / / www.statista.com/statistics/274774/forecast-of-mobile-phone-users-worldwide/ (accessed on 12 January 2017).

33. Worldometers. Current World Population. Available online: http://www.worldometers.info/worldpopulation (accessed on 12 January 2017).

34. The Statistics Portal. Number of mobile phone users in Brazil from 2013 to 2019 (in millions). Available online: https:/ / www.statista.com/statistics/274695/forecast-of-mobile-phone-users-in-brazil/ (accessed on 12 January 2017).

35. Worldometers. Brazil Population. Available online: http://www.worldometers.info/world-population/ brazil-population/ (accessed on 12 January 2017).

36. Jones, A.; Issroff, K.; Scanlon, E. Affective factors in learning with mobile devices. In Big Issues in Mobile Learning; Sharples, M., Ed.; University of Nottingham: Nottingham, UK, 2007; pp. 17-22.

37. Kukulska-Hulme, A.; Norris, L.; Donohue, J. Mobile Pedagogy for English Language Teaching: A Guide for Teachers; Other Mobile Pedagogy for English Language Teaching: A Guide for Teachers; ELT Research Papers 14.07; British Council: London, UK, 2007.

38. Medrado, B.P. Deficiência Visual e Ensino de Linguas Estrangeiras: Políticas, Formação e Ações Inclusivas; Pontes Editora: Campinas, Brazil, 2014.

39. Retorta, M.S.; Bork, A.V.B. Tecnologia assistiva no ensino de língua inglesa como língua adicional para cegos. In Linguagem e Educação: Ensinoaprendizagem e Formação de Professores de Linguas. Uma Homenagem à Professora Vera Cristóvão; Beato-Canato, A.P.M., Quevedo-Camargo, G., Eds.; Pontes Editora: Campinas, Brazil, 2015.

40. Universidade Federal do Rio de Janeiro PROJETO DOSVOX. Available online: http:/ /intervox.nce.ufrj.br/ dosvox/ (accessed on 26 January 2017).

41. Curran, M. NVDA-Acesso Não-Visual ao Ambiente de Trabalho. Available online: http://www. acessibilidadelegal.com/33-nvda.php (accessed on 26 January 2017).

42. Freedom Scientific. JAWS-Job Access With Speech. Available online: http://www.freedomscientific.com/ Products/Blindness/JAWS (accessed on 26 January 2017).

43. Czarneski, C.C.O. Uso do Facebook Como AVA no Ensino de Lingua Inglesa Para Cegos; Federal University of Technology-Paraná: Curitiba, Brazil, 2015.

44. Oliveira, R.S. The Use of ICT in Teaching English as an Additional Language for Blind and Visually Impaired: A Case of Study; Federal University of Technology-Paraná: Curitiba, Brazil, 2015.

45. Glister, P. Digital Literacy; Wiley Computer Publications: New York, NY, USA, 1999.

46. Lúcio, H.R.T. O Papel dos Podcasts na Aprendizagem do Inglês Como Língua Adicional: Experiência de Alunos Cegos e de Baixa Visão em um Curso de Extensão; Federal University of Technology-Paraná: Curitiba, Brazil.

47. Delgado, L.T.; Leal, E.D.C.A.; Guerrero, R.L.G.; Vela, U.M.; Hernández, A.J.G. Inclusión del Podcast en la educación básica: Una estrategia didáctica para alumnos con discapacidad visual. Rev. Electrónica Sobre Tecnol. Educ. Y Soc. 2017, 4, 1-13.

48. Burston, J. Mobile-Assisted Language Learning: A Selected Annotated Bibliography of Implementation Studies 1994-2012. Lang. Learn. Technol. 2013, 17, 157-225.

49. Watson-Gegeo, K.A. Classroom Ethnography. In Encyclopedia of Language and Education, Volume 8: Research Methods in Language and Education; Hornberger, N., Corson, P., Eds.; Kluwer Academic Publishers: Berlin, Germany, 1997; pp. 135-144. 
50. Executive Secretariat of the InterAgency Commission. Meeting Basic Learning Needs: A Vision for the 1990s; Background Document World Conference on Education for All Meeting Basic Learning Needs, Jomtien, Thailand, 5-9 March 1990; UNICEF: New York, NY, USA, 1990.

51. Ministério da Educação. Política Nacional de Educação Especial na perspectiva da Inclusão. In Ministério da Educação; 2008; p. 19. 